\title{
Constitutionalism Outside the Courts
}

Ernest A. Young*

In September of 1957, Governor Orval Faubus of Arkansas ordered the National Guard to prevent black students from entering Central High School in Little Rock. The nine students sought to enter pursuant to a desegregation plan adopted by the Little Rock School Board to comply with the U.S. Supreme Court's decisions in Brown v. Board of Education. ${ }^{1}$ Brown had held that racially segregated public schools were unconstitutional, but Faubus disagreed. With Faubus's support, the Arkansas legislature had enacted "interposition" legislation, which directed the state to prevent enforcement of Brown until such time as the states could ratify a constitutional amendment shifting power over integration from the courts to Congress. ${ }^{2}$ Faubus filed suit in the state courts to block desegregation in Little Rock, and-citing fears of violence arising from the controversy over the City's schools - he ordered the National Guard to prevent any further steps toward integration and maintain order. ${ }^{3}$

Governor Faubus's suit was unsuccessful, and President Eisenhower ultimately deployed federal troops to ensure the black students' safety. Continuing public turmoil outside the school, however, led the school board to ask the federal district court to postpone implementation of the desegregation plan. That court agreed, but the case-now known as Cooper v. Aaron ${ }^{4}$ - went up to the U.S. Supreme Court. A remarkable opinion signed by all nine justices, declared that " $[\mathrm{t}]$ he constitutional rights of [the black students] are not to be sacrificed or yielded to the violence and disorder which have followed upon the actions of the Governor and Legislature."

\footnotetext{
* Alston \& Bird Professor, Duke Law School. This essay is for my friend Sandy Levinson, who taught me that it is possible to love the Constitution deeply while questioning nearly everything about it.

${ }^{1}$ See Brown v. Board of Education (Brown I), 347 U.S. 483 (1954) (holding that racial segregation in the public schools is unconstitutional); Brown v. Board of Education (Brown II), 349 U.S. 294 (1955) (ordering local school districts to desegregate "with all deliberate speed").

${ }^{2}$ See Tony A. Freyer, Politics and Law in the Little Rock Crisis, 1954-1957, 66 ARK. Hist. QUARTERLY 145, 153-57 (2007).

${ }^{3}$ See id. at 157-60; Speech of Gov. Orval E. Faubus, Sept. 2, 1957, available at http://www.southerncolloqrhetoric.net/web/resources/Faubus570902.pdf.

4358 U.S. 1 (1958).

${ }^{5} \mathrm{Id}$. at 16 .
} 
premise of the actions of the Governor and Legislature that they are not bound by our holding in the Brown case." Invoking "basic constitutional propositions," the Court insisted that "that the federal judiciary is supreme in the exposition of the law of the Constitution. . . . It follows that the interpretation of the Fourteenth Amendment enunciated by this Court in the Brown case is the supreme law of the land" and therefore binding on all state officials, including Governor Faubus. ${ }^{7}$

No one today doubts that Cooper's result. Scholars and judges have had considerably more trouble, however, with the Court's statement that "the federal judiciary is supreme in the exposition of the law of the Constitution." During the Reagan years, Attorney General Edwin Meese challenged judicial supremacy as a way of attacking liberal precedents like Roe v. Wade. ${ }^{8}$ And as the Court turned (somewhat) to the right under Chief Justices Burger, Rehnquist, and Roberts, liberal academics began to talk about "taking the Constitution away from the courts." Other scholars have stressed the positive contributions to constitutional development of legislators, executive branch officials, and popular social movements. ${ }^{10}$ And both lawyers and judges have had to grapple with difficult questions concerning the deference owed to constitutional interpretations by other government institutions. ${ }^{11}$

The assault on judicial supremacy has had the salutary effect of highlighting both the limits of judicial review and the important roles that other actors play in shaping constitutional meaning. Outside the academy, however, there is little evidence of public dissatisfaction with judicial review or enthusiasm for alternative forms of popular constitutionalism. This, I submit, is because the

${ }^{6} I d$. at 17 .

${ }^{7} I d$. at 18 .

${ }^{8} 410$ U.S. 113 (1973); see Edwin Meese III, The Law of the Constitution, 61 TUlane L. ReV. 979 (1987).

${ }^{9}$ MARK TUSHNET, TAKING THE CONSTITUTION AWAY FROM THE COURTS (1999); see also LARry Kramer, THE PeOPle Themselves: Popular CONSTITUTIONALISM AND JUDICIAL REVIEW (2004).

${ }^{10}$ See, e.g., William N. Eskridge, Jr., \& John Ferejohn: A Republic of Statutes: The New American Constitution (2010); Jack M. Balkin, How Social Movements Change (or Fail to Change) the Constitution: The Case of the New Departure, 39 Suffolk U. L. Rev. 27 (2005); Keith E. Whittington, Constitutional Construction: Divided Powers and Constitutional MEANING (1999).

${ }^{11}$ See, e.g., City of Boerne v. Flores, 521 U.S. 507 (1997) (exploring Congress's authority to interpret the Constitution pursuant to its power to enforce the Reconstruction Amendments). 
important rule of law function fulfilled by the Supreme Court has never amounted to "judicial supremacy" in the first place.

\section{The Revolt Against Judicial Supremacy}

Article VI of the Constitution requires all public officials, state and national, to swear an oath "to support this Constitution." 12 All lawyers and military personnel make a similar promise. ${ }^{13}$ The breadth of this commitment makes any notion that the Constitution somehow "belongs" to the courts hard to sustain. Each of these posts, after all, may require constitutional judgmentswhether it is a President deciding whether or not to sign a bill, a soldier determining whether to follow an order, or a policeman considering whether he may legally search a house.

All naturalized citizens, moreover, must take a similar oath. ${ }^{14}$ This reflects the fact that all citizens are frequently invited to consider arguments about the constitutionality of various laws and proposals or to assess which would-be officials would be the best guardians of constitutional values. ${ }^{15}$ And of course many social movements, from the civil rights movement to the Tea Party, have framed their arguments in explicitly constitutional terms. Everyone involved in Cooper-including Governor Faubus, President Eisenhower, the Arkansas legislature, the Little Rock School Board, and even the private citizens gathered outside the high school — had not only a right but an obligation to interpret the Constitution as it bore on the situation before them (although many of them undoubtedly got the Constitution wrong).

${ }^{12}$ U.S. ConST. art. VI, cl.3.

13 See, e.g., State Bar of Texas, Oath of Office Form, https://www.texasbar.com/Content/NavigationMenu/ForLawyers/MembershipInf oandServices/NewLawyerFormsFees/OathofOfficeForm.pdf (visited April 19, 2014); U.S. Army Center of Military History, Oaths of Enlistment and Oaths of Office, http://www.history.army.mil/html/faq/oaths.html (visited April 19, 2014).

${ }^{14}$ U.S. Citizenship and Immigration Services, Naturalization Oath of Allegiance to the United States of America, http://www.uscis.gov/uscitizenship/naturalization-test/naturalization-oath-allegiance-united-states-america (visited April 19, 2014).

${ }^{15}$ See, e.g., Sen. Barack Obama, Speech at the Woodrow Wilson International Center, Aug. 1, 2007, available at http://www.cfr.org/elections/obamas-speechwoodrow-wilson-center/p13974 (promising to "provide our intelligence and law enforcement agencies with the tools they need to track and take out the terrorists without undermining our Constitution and our freedom"). 
In this sense, as Sanford Levinson has pointed out, America espouses a "Protestant" approach to constitutional meaning. ${ }^{16}$ We have a "priesthood of all [constitutional] believers," in which each individual can read and interpret the constitutional text for himself. And yet, we also undeniably have a "priesthood" whose interpretations have a privileged role. The literature on judicial review and popular constitutionalism arises out of this tension.

\section{A. Marbury and Departmentalism}

Cooper's declaration of judicial supremacy relied directly on Chief Justice John Marshall's statement in Marbury v. Madison ${ }^{17}$ that "[i]t is emphatically the province and duty of the judicial department to say what the law is."18 But the two cases raised quite different issues. Marbury concerned the Court's ability to set aside a federal statute that contravened the Constitution in the course of resolving a litigated dispute. Governor Faubus's challenge to the Court's authority in Cooper, on the other hand, concerned the binding effect of Supreme Court precedents on nonjudicial actors not party to a prior decision. The conceptual daylight between these two questions gives rise to a widely-accepted form of constitutionalism outside the courts: the departmentalist view that each institution of government can (and must) interpret the Constitution for itself in the course of its own institutional responsibilities. ${ }^{19}$

Marbury was difficult precisely because Congress, as well as the judiciary, is obliged to interpret the Constitution. Congress, after all, presumably thought that it was acting consistently with the constitution when it enacted the Judiciary Act's provision at issue in Marbury. Chief Justice Marshall's opinion readily established the Constitution's supremacy over a conflicting statute, ${ }^{20}$ but that hardly establishes that the Court's interpretation of the Constitution is supreme over Congress's. ${ }^{21}$ The best reading of Marbury insists simply that the Court has jurisdiction to consider cases "arising under" the Constitution, and that when it

${ }^{16}$ See SANFord LEVInSON, Constitutional FAith 27-53 (1988).

${ }^{17} 5$ U.S. (1 Cranch) 137 (1803).

${ }^{18} \mathrm{Id}$. at 177; see Cooper, 358 U.S. at 18 (relying on this language).

${ }^{19}$ See, e.g., Walter F. Murphy, Who Shall Interpret? The Quest for the Ultimate Constitutional Interpreter, 48 REV. OF Politics 401, 411-12 (1986).

${ }^{20}$ See 5 U.S. (1 Cranch) at 176 (considering "whether an Act repugnant to the Constitution can become the law of the land").

${ }^{21}$ See, e.g., William W. Van Alstyne, A Critical Guide to Marbury v. Madison, 1969 DUKE L. J. 1, 21-22. 
does so it need not defer to other branches' interpretations of that document. ${ }^{22}$ But that reading simply does not speak to other political actors' obligations to defer (or not) to the judiciary's interpretations. ${ }^{23}$

Thomas Jefferson articulated the departmentalist alternative to judicial supremacy by refusing to view "judges as the ultimate arbiters of all constitutional questions"; rather, he said, "[t] he constitution has erected no such single tribunal . ... It has more wisely made all the departments co-equal and co-sovereign within themselves." 24 This position better fits Marshall's reasoning in Marbury. If the power to interpret the Constitution judicial review stems from the performance of the Court's underlying judicial function, then similar authority would seem to stem from Congress's and the President's performance of their functions.

The trouble with departmentalism is that constitutional functions often overlap. Congress passes a law, exercising its judgment that the law is constitutional, but then someone challenges that law in a court. Our tradition, consolidated when President Nixon turned over the tapes, ${ }^{25}$ is that the authority of non-judicial officials to interpret the Constitution for themselves does not extend to defying court orders. That is enough to decide Cooper, given that Governor

${ }^{22}$ See Richard H. FAllon, JR., John F. Manning, Daniel J. Meltzer, \& DaVid L. Shapiro, Hart and Wechsler's The Federal Courts and the Federal SYSTEM 72-73 (6th ed. 2009).

${ }^{23}$ See, e.g., Murphy, supra note 19, at 406-07 (observing that it is "a long step from judicial review - the authority of a court, when deciding cases, to refuse to give force to an act of a coordinate branch of government - to judicial supremacy, the obligation of coordinate officials not only to obey that ruling but to follow its reasoning in future deliberations").

${ }^{24}$ Thomas Jefferson, Letter to William Jarvis, Sept. 28, 1820, in 12 PAUL L. Ford, ED., THE WORKS OF THOMAS JEFFERSON 161-64 (1905). Three other positions have been proposed: legislative supremacy, executive supremacy, and "confederational departmentalism." See Murphy, supra note 19, at 410-11, 420 n.28. Marbury rejected legislative supremacy, and the only serious attempt to revive it - by the Radical Republicans of Reconstruction - did not last. As Professor Murphy points out, "constitutionalism is wary of arguments that allow popularly elected officials final authority to define substantive rights. . . . One does not, as the Italian proverb goes, make the goat one's gardener." Id. at 411. Few argue for executive supremacy in constitutional interpretation. On "confederational departmentalism," see infra text accompanying notes 38-Error! Bookmark not defined..

${ }^{25}$ See United States v. Nixon, 418 U.S. 683 (1974). 
Faubus's actions interfered with the federal district court's decree in the Little Rock desegregation litigation. ${ }^{26}$

This "modified version" of departmentalism ${ }^{27}$ acknowledges that courts will often have the last (and binding) word, but it tempers that concession to judicial supremacy in two ways. First, there are many questions that the courts cannot decide. These include disputes over constitutional meaning that never take the form of an Article III "case or controversy," as well as those that are nonjusticiable "political questions." Although the contemporary Court has tended to define "political questions" quite narrowly, ${ }^{28}$ its restrictive doctrine of standing leaves many constitutional disputes outside the federal courts' jurisdiction. ${ }^{29}$ Second, the doctrinal tests by which courts decide constitutional questions frequently incorporate substantial deference to political actors. ${ }^{30}$ John Marshall's test for federal legislation under the Necessary and Proper Clause, for example, largely accepted legislative judgments of "necessity" as binding on the courts. ${ }^{31}$

A thornier difficulty stems from the distinction between the judgment and precedential force of judicial decisions. Political actors may not defy judicial pronouncements of constitutional meaning when they are parties to a judgment in a litigated case, but what about when they are not? Can they simply ignore the Supreme Court's interpretation and continue to act according to their own reading? If there had been no judicial decree in Cooper, then Governor Faubus's action in excluding the black students from Central High School would have defied the precedential force of Brown but contravened no judgment. Some opponents of judicial supremacy have suggested that a decision's res judicata force is all that binds, and that political actors have no obligation to follow a

${ }^{26}$ See Daniel A. Farber, The Supreme Court and the Rule of Law: Cooper v. Aaron Revisited, 1982 U. ILL. L. REV. 387, 394.

${ }^{27}$ Murphy, supra note 19, at417.

${ }^{28}$ See, e.g., Zivotofsky v. Clinton, 132 S. Ct. 1241 (2012); Baker v. Carr, 369 U.S. 186 (1962).

${ }^{29}$ See, e.g., Hollingsworth v. Perry, 133 S. Ct. 2652 (2013); Clapper v. Amnesty Int'l USA, 133 S. Ct. 1138 (2013); Raines v. Byrd, 521 U.S. 811 (1997).

${ }^{30}$ See, e.g., FCC v. Beach Communications, Inc., 508 U.S. 307, 314-15 (1993) (describing the "rational basis" standard for constitutional claims not involving a suspect classification or a fundamental right).

${ }^{31}$ See McCulloch v. Maryland, 17 U.S. (4 Wheat.) 316 (1819). 
judicial precedent with which they disagree so long as they were not parties to the litigation. ${ }^{32}$

This suggestion founders on the fact that courts hold government officials liable all the time for violating constitutional interpretations pronounced in litigation to which they were not parties. As Dan Farber has pointed out, "[i]t is simply wrong to say that constitutional rules can be violated with impunity until after entry of an enforcement decree." ${ }^{33}$ Both state and federal officials may be sued for damages when they violate the Constitution, and they will be liable if they violated "clearly established law"-even if the relevant constitutional meaning is "established" only by judicial opinions. ${ }^{34}$ This retrospective liability rests on a constitutional wrong occurring at a time when the official was not subject to any judicial decree. Such liability makes sense only if governmental officials are bound not only by judicial judgments, but also by judicial precedents. ${ }^{35}$

The remedial law reflects a pragmatic balance between respect for political actors' authority to interpret the Constitution and the rule-of-law interests in preventing infringements of individuals' rights. When courts issue prospective decrees against governmental officials, they apply their own unmediated view of constitutional meaning; when courts impose retrospective liability for violation of a prior precedent, however, non-judicial actors have a "good faith" or "reasonableness" defense. This provides some interpretive leeway for government officials operating in areas in which the Constitution's meaning remains ambiguous or disputed. At the same time, government officials may not act with impunity against persons who have not already secured an injunction against unconstitutional action. ${ }^{36}$ Such remedies are a significant departure from departmentalism; after all, the reasonableness of an officer's conduct is measured against judicial precedents. That this departure is so well established ${ }^{37}$

32 See, e.g., Meese, supra note 8; AleXANDER M. Bickel, THE LeAST Dangerous Branch: The Supreme Court at the Bar of Politics 263-64 (1962) (arguing that Southern officials were bound to accept Brown only when they became parties to specific judicial decrees).

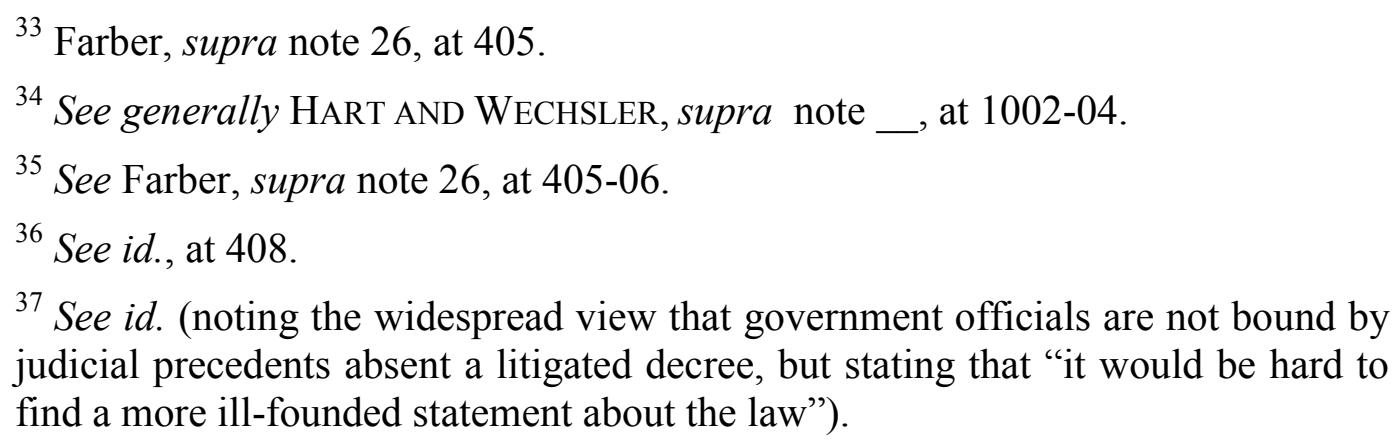


demonstrates the extent to which our constitutional regime sees some degree of judicial supremacy as necessary to the rule of law.

A final point about departmentalism: There is no logical reason to restrict the power to interpret the Constitution to branches of the federal government. Professor Murphy equated "confederational departmentalism"-which entails only that state governmental officials, like federal ones, must interpret the Constitution in the course of their own duties - with "nullification," which "held the states to be the final interpreters." ${ }^{38}$ That hardly follows. After all, Congress's departmental right to interpret the Constitution when it legislates is not the same thing as legislative supremacy. State officials' constitutional interpretations are subject to the same constraints that federal non-judicial interpretations are - that is, they remain subject to the possibility of federal judicial review, including retrospective damages liability when state officials violate clearly established law. Governor Faubus was not wrong to disagree with the Supreme Court in Cooper simply because he was a state official. The problem was that he interfered with a federal court order in a pending case- and that he got the meaning of the Constitution wrong.

\section{B. Judicial Efficacy and the "Hollow Hope"}

A quite different challenge to judicial supremacy concerns the practical limits of judicial efficacy rather than the theoretical limits of judicial authority. Alexander Hamilton famously said that "the judiciary ... will always be the least dangerous [branch] to the political rights of the Constitution," because it "has no influence over either the sword or the purse; no direction either of the strength or of the wealth of the society, and can take no active resolution whatever." "It may truly be said to have neither force nor will," Hamilton insisted, "but merely judgment; and must ultimately depend upon the aid of the executive arm even for the efficacy of its judgments." 40 Working in this Hamiltonian tradition, contemporary analysts have persuasively questioned the courts' ability to effect significant social change without assistance from other institutional actors.

The most prominent critic in this vein, Gerald Rosenberg, emphasizes the limits of the Court's accomplishment in Brown. ${ }^{41}$ That case held segregated schooling unconstitutional; its remedial sequel ordered segregated school districts

${ }^{38}$ Murphy, supra note 19, at 420 n.28 (emphasis added); see also id. (arguing that "the Civil War effectively invalidated such claims").

${ }^{39}$ The Federalist No. 78, at 522 (Jacob E. Cooke, ed., 1961) (Alexander Hamilton).

${ }^{40} I d$. at 523.

${ }^{41}$ See Gerald Rosenberg, The Hollow Hope: Can Courts Bring About Social CHANGe? 42-106 (1991). 
to integrate. Follow-on decisions not only rejected state officials' right to challenge Brown but held efforts to circumvent it unconstitutional. ${ }^{42}$ In all these cases, Professor Rosenberg points out, "the Court had spoken clearly and forcefully." ${ }^{43}$ Moreover, during the ten-year period after Brown, Congress and the Executive remained largely silent on desegregation; hence, "[t]he decade from 1954 to 1964 provides close to an ideal setting for measuring the contribution of the courts vis-à-vis Congress and the executive branch in desegregating public schools." ${ }^{44}$ The results are striking - and quite sobering to notions of judicial supremacy. In the Southern states, "[f]or ten years, 1954-64, virtually nothing happened. Ten years after Brown only 1.2 percent of black schoolchildren in the South attended school with whites." ${ }^{45}$ The situation radically changed, however, once Congress enacted the 1964 Civil Rights Act, which authorized the Attorney General to bring federal desegregation suits on behalf of individuals, and the 1965 Elementary and Secondary Education Act, which provided a huge pot of federal aid money to public school districts but made that money contingent on steps toward desegregation. By the 1972-73 school year, over 91 percent of black schoolchildren attended school with whites. ${ }^{46}$ Rosenberg concluded that "Brown and its progeny stand for the proposition that courts are impotent to produce significant social reform., ${ }^{47}$

One might offer a number of rejoinders to Professor Rosenberg's account, the most persuasive being that judicial actions-particularly the Brown decision - play a catalytic role by inspiring social movements and spurring other governmental actors to action. Historian David Garrow has written, for example, of "the direct influence of Brown on the instigation of the 1955 Montgomery [bus] boycott. Almost every significant black Montgomery activist of that time has without prompting spoken of Brown's importance for the bus protesters." ${ }^{48}$

${ }^{42}$ See Cooper v. Aaron, 358 U.S. 1 (1958); Goss v. Board of Education of Knoxville, 373 U.S. 683 (1963); Griffin v. Prince Edward Cty., 377 U.S. 218 (1964).

${ }^{43}$ ROSENBERG, supra note 41 , at 45.

${ }^{44} \mathrm{Id}$. at 49.

${ }^{45} \mathrm{Id}$. at 52 .

${ }^{46}$ See id. at 50. One may quibble with Professor Rosenberg's generous definition of "desegregation," but the point is the magnitude of the change in that measure of desegregation over time.

${ }^{47} I d$. at 71 .

${ }^{48}$ David Garrow, Hopelessly Hollow History: Revisionist Devaluing of Brown v. Board of Education, 80 VA. L. REV. 151, 152-53 (1994). But see Michael J. Klarman, Brown, Racial Change, and the Civil Rights Movement, 80 VA. L. REV. 
Moreover, judicial decisions may play a more central role in particular settingsfor example, in defending reformers from attacks and, more generally, in protecting the sorts of political freedoms that make reform possible. ${ }^{49}$ But in each of these scenarios, judges play a supporting role to non-judicial actors, particularly broad social movements, that pursue their constitutional vision primarily outside the courts. Vigorous debate persists concerning the extent to which judicial decisions matter out in the world, but no one believes anymore that constitutionalism inside the courts can go it alone.

\section{Popular Constitutionalism}

The most prominent contemporary theories of constitutionalism outside the courts now parade under the banner of "popular constitutionalism." Popular constitutionalists are highly critical of judicial review, although they differ in their prescriptions. Mark Tushnet proposes "taking the Constitution away from the courts" entirely, while Larry Kramer proposes "judicial review without judicial supremacy." ${ }^{50}$ Both urge that people outside the professional community of lawyers, judges, and bureaucrats should play a greater role in constitutional interpretation. But popular constitutionalism's proponents remain resolutely ambiguous about the affirmative meaning of their theory - that is, the manner in which "the People themselves," in Larry Kramer's phrase, can implement their own views of constitutional meaning.

Professor Tushnet's thesis is the easier to parse. He proposes that the Supreme Court simply swear off judicial review, ${ }^{51}$ leaving political actors to interpret the Constitution for themselves in the course of political debate. He also introduces a distinction between a "thin Constitution"-the good parts, comprising mostly the Preamble and the Declaration of Independence-and a "thick constitution" consisting of "detailed provisions describing how the government is to be organized." 52 "Populist constitutional law vindicates the thin constitution," Tushnet says; is is "a law oriented to realizing the principles of the

7, 82 n. 353 (1994) (concluding that "the Brown decision was a relatively unimportant motivating factor for the civil rights movement").

${ }^{49}$ See, e.g., New York Times, Inc. v. Sullivan, 378 U.S. 254 (1964) (relying on the Free Speech Clause of the First Amendment to prevent use of libel litigation to deter coverage of the civil rights movement by news organizations); Garner v. Louisiana, 368 U.S. 157 (1961) (overturning convictions of civil rights protesters involved in lunch counter sit-ins on due process grounds).

${ }^{50}$ See TUSHNET, supra note 9; KRAMER, supra note Error! Bookmark not defined.

${ }^{51}$ See TUSHNET, supra note 9, at 154.

${ }^{52} I d$. at 9-12. 
Declaration of Independence and the Constitution's Preamble."53 In the absence of judicial review, this thin constitution-the "fundamental guarantees of equality, freedom of expression, and liberty" - would guide political actors in fulfilling the social project begun by the Declaration. ${ }^{54}$

Professor Tushnet's distinction between the "thick" and "thin" constitutions seems to play a pivotal role in populist constitutionalism. Presumably populist mobilization, necessary to make the views of the broader people count in constitutional debate, is unlikely with respect to the institutional detail that comprises the thick constitution; these details, in his view, do not "thrill the heart." It is true that Madison did not stress judicial review as a mechanism for enforcing the Constitution's institutional structure, ${ }^{56}$ and later theorists have urged that principles of federalism and separation of powers can be left to "political safeguards." "57 As I discuss in Part II, this sort of political enforcement itself represents an important form of constitutionalism outside the courts.

And yet much of the key business of judicial review involves the policing of institutional boundary disputes. ${ }^{58}$ Erin Delaney and Barry Friedman have argued that the Supreme Court's pivotal role in constitutional interpretation developed out of the need to referee federalism disputes between the national government and the states. ${ }^{59}$ And the Court hears a significant number of cases each term involving the preemption of state law by federal statutes under the

${ }^{53} I d$. at $12,181$.

${ }^{54} I d$. at $11,31$.

55 Id. at 10 .

${ }^{56}$ See The Federalist No. 51, supra note 39, at 347-53 (James Madison) (stressing non-judicial checks and balances).

${ }^{57}$ See, e.g., Herbert Wechsler, The Political Safeguards of Federalism: The Role of the States in the Composition and Selection of the National Government, 54 Colum. L. Rev. 543 (1954); Jesse H. ChOper, Judicial REvieW AND THE National Political Process: A Functional Reconsideration of the Role OF THE SUPREME COURT (1980).

${ }^{58}$ See, e.g., Zivotofsky v. Clinton, 132 S. Ct. 1421 (2012) (rejecting arguments that a dispute over whether the President or Congress had power to dictate the contents of a passport issued to a child born in Jerusalem was a nonjusticiable political question).

59 See Barry Friedman \& Erin Delaney, Becoming Supreme: The Federal Foundations of Judicial Supremacy, 111 CoLUM. L. REV. 1137 (2011). 
Supremacy Clause ${ }^{60}$ - a provision that Professor Tushnet would relegate to the "thick" constitution but that formed a central part of the Founders' design. The point is twofold: First, it is not at all clear that one could eliminate judicial review of these institutional boundary issues without profoundly altering the operation of the governmental system in ways that popular constitutionalists have not fully investigated. Second, the Founders viewed the structural provisions of the thick constitution - the proposal of 1789, which lacked a Bill of Rights, much less a Fourteenth Amendment - as the key to vindicating the principles of the thin constitution. ${ }^{61}$ The Preamble, after all, is only a preamble. To say that the Constitution's institutional arrangements should be vindicated neither by judicial review nor by populist constitutionalism is to tear the heart out of their constitutional project.

It is not surprising, then, that Professor Tushnet quickly points out that a world without constitutional judicial review might nonetheless preserve means for courts to police boundaries and check arbitrary governmental behavior. ${ }^{62}$ But it is unclear why statutory or common law review would not raise the same problems that lead populist scholars to criticize judicial review in the first place. Is the "arbitrary and capricious" standard in administrative law really less open-ended and judge-empowering than the various doctrines of constitutional law? The most controversial case of the present Supreme Court term is Sebelius v. Hobby Lobby Stores, Inc. ${ }^{63}$ which concerns whether religiously-oriented corporations that object to certain forms of contraception are entitled to an exemption from the contraceptive mandate of the Affordable Care Act. The difficulties of judicial review in that case are hardly lessened by the fact that the plaintiffs' primary claims are under the Religious Freedom Restoration Act-a statute ${ }^{64}$-rather than the Free Exercise Clause of the Constitution. In any event, relying on nonconstitutional forms of review to check political actors is neither "populist" nor "outside the courts."

${ }^{60}$ See, e.g., Ernest A. Young, "The Ordinary Diet of the Law": The Presumption Against Preemption in the Roberts Court, 2011 SUP. CT. REV. 253.

${ }^{61}$ See, e.g., Ernest A. Young, Welcome to the Dark Side: Liberals Rediscover Federalism in the Wake of the War on Terror, 69 BROOKLYN L. REV. 1277, 128485 (2004).

${ }^{62}$ See TUSHNET, supra note 9 , at 163-65 (pointing out that "[a] great deal of what we in the United States know as constitutional law parades in Great Britain as administrative law").

${ }^{63}$ No. 13-354 (October Term 1013).

${ }^{64} 42$ U.S.C. $\S \S 2000$ bb to 2000 bb-4. 
Dean Kramer's popular constitutionalism would not abolish judicial review outright; instead, he proposes "judicial review without judicial supremacy." ${ }^{65}$ As I have already discussed, one may wonder how much judicial supremacy there really is in contemporary America; so many situations arise in which judicial review is unlikely or judicial remedies are limited that our system resembles Professor Murphy's "modified" departmentalism. Kramer's prescription appears to add two related elements. First, he evidently believes that the substantive standard of judicial review should be more deferential in particular areas - especially the aspects of federalism doctrine that limit national power. ${ }^{66}$ Second, he would subject the Supreme Court to the ultimate check of popular will. He urges his countrymen to "insist[] that the Supreme Court is our servant and not our master: a servant whose seriousness and knowledge deserves much deference, but who is ultimately supposed to yield to our judgments about what the Constitution means and not the reverse." At the end of the day, Kramer insists, "[t]he Supreme Court is not the highest authority in the land on constitutional law. We are." $" 67$

It is hard to quarrel with Dean Kramer's plea for the public to take a greater interest in constitutional law, but beyond that it is hard to know what to make of his proposal. He points out that "[t] $\mathrm{the}$ Constitution leaves room for countless political responses to an overly assertive Court: Justices can be impeached, the President can ignore its mandates, Congress can strip it of jurisdiction or shrink its size or pack it with new members or give it burdensome new responsibilities or revise its procedures. ${ }^{\prime 68}$ These prescriptions are a recipe for exponential escalation of the partisan rancor that has divided Washington, D.C. in the past several years. But Kramer also cites incidents of "extralegal violence" and "mobbing" as "traditional forms of popular constitutionalism." 69

Scot Powe points out in a devastating review that the most prominent example of Kramerian popular constitutionalism in recent memory is the South's "Massive Resistance" to the Court's decision in Brown. ${ }^{70}$ Resistance took multiple forms, from the "Southern Manifesto," signed by eighty percent of Southern senators and representatives, criticizing the Court's constitutional

${ }^{65}$ KRAMER, supra note 9, at 249.

${ }^{66}$ See Larry Kramer, The Supreme Court, 2000 Term-Foreword: We the Court, 115 HARV. L. REV. 4, 138-53 (2001).

${ }^{67}$ KRAMER, supra note 9, at 248.

${ }^{68}$ KRAMER, supra note 9, at 249.

${ }^{69}$ Id. at 110 .

${ }^{70}$ L. A. Powe, Jr., Are "the People" Missing in Action (and Should Anyone Care)? 83 TEXAS L. REV. 855, 866-70 (2005) (book review). 
interpretation in Brown, to the state laws purporting to block Brown's implementation through "interposition" or circumvent its mandate through various dodges, to the mob outside Central High School in Little Rock seeking to intimidate black students and prevent them from entering. Dean Kramer does not discuss massive resistance, and he offers no criteria that might distinguish it from legitimate instances of popular constitutionalism. ${ }^{71}$ Just as it has become impossible to advocate a theory of constitutional interpretation that cannot support Brown, ${ }^{72}$ it is hard to take seriously a theory of interpretive authority that condones the South's massive resistance to that decision.

It is worth noting that despite the moniker, "popular constitutionalism" is a highly elite and almost entirely academic movement. "[S]upporters of judicial supremacy are today's aristocrats," accuses Larry Kramer-the former dean of the Stanford Law School and now President of the multi-billion dollar Hewlett Foundation. $^{73}$ Of course, most populist movements have elite leadership. But there is little evidence that the distrust of judicial review felt by these scholars is widely shared. A leading survey taken in 2001-the year after Bush v. Gorefound "a remarkably high level of loyalty toward the Supreme Court on the part of most Americans." 74 In particular, 69.2 percent of respondents agreed with the

${ }^{71}$ See id. at 870 . In an essay generally defending Kramer, Mark Tushnet seems to concede that massive resistance counts as popular constitutionalism; he suggests only that other popular mobilizations, such as the civil rights movement itself, may have done enough good to outweigh the harm of massive resistance. See Mark V. Tushnet, Popular Constitutionalism as Political Law, 81 CHI.-Kent L. REV. 991, 994 n.10, 1004 n.49 (2006). Of course, one can acknowledge the role of social movements in persuading lawyers and judges to change their view of the Constitution and in prompting the political branches to add their enforcement powers to judicial remedies without condoning outright defiance of judicial orders or "extralegal violence."

${ }^{72}$ See TUSHNET, supra note 9, at 156.

${ }^{73}$ Similarly, Mark Tushnet is the William Nelson Cromwell Professor of Law at the Harvard Law School. My own view is that this couldn't have happened to a nicer (or more deserving) guy, but then I am not a populist.

${ }^{74}$ James L. Gibson, Gregory A. Caldeira, \& Lester Kenyatta Spence, Measuring Attitudes toward the United States Supreme Court, 47 AM. J. PoL. SCI. 354, 358 (2003). Professor Gibson performed a later survey in 2005 that confirmed his earlier findings. See James L. Gibson, The Legitimacy of the United States Supreme Court in a Polarized Polity, 4 J. EmPIRICAL Legal Stud. 507, 532 (2007) (finding that "the U.S. Supreme Court is widely supported by the American people, and that support has little to do with ideology or partisanship"); see also Manoj Mate \& Matthew Wright, The 2000 Presidential Election 
proposition that "[t]he U.S. Supreme Court should have the right to say what the Constitution means, even when the majority of the people disagree with the Court's decision." 75 Moreover, "a great deal of loyalty to the institution can be found even among those who have hardly any confidence in the Court. For instance, the vast majority of those who have little confidence in the Court are nonetheless unwilling to support doing away with the institution." 76 These findings strongly suggest that, even if public confidence in the Court's present performance fluctuates, ${ }^{77}$ the Court's diffuse support is sufficiently strong to make calls for popular constitutionalism distinctly unpopular.

Proponents of popular constitutionalism generally acknowledge the broad public support for judicial review; as Dean Kramer puts it, "everyone nowadays seems willing to accept the Court's word as final." 78 Kramer offers several reasons: "heightened skepticism about popular democracy occasioned by twentieth-century totalitarianism; the historical anomaly of the liberal Warren Court; two generations of near consensus about judicial supremacy among intellectuals and opinion-makers on both the left and the right (not to mention among high school civics teachers)." ${ }^{, 79}$ One may or may not agree with these reasons, but it is implausible to describe 69.2 percent of the population as "today's aristocrats." And even if we can attribute such deep-seated public approval of the Court to false consciousness, it means as a practical matter that radical visions of popular constitutionalism are unlikely to get off the ground.

There is another possibility, however. The public may approve of judicial review because it senses that, over time, the Court is in fact reasonably responsive

Controversy, in NAthaniel Persily, Jack Citrin, \& PAtRick J. Egan, eds., Public OPINION AND CONSTITUTIONAL CONTROVERSY 333 (2008) (concluding that strong public support for the Court had recovered from any loss of legitimacy occasioned by the Court's ruling in Bush v. Gore).

${ }^{75}$ Gibson, Caldeira, \& Spence, supra note 74 at 358 (Table 2).

${ }^{76} I d$. at 361 (emphasis in original).

${ }^{77}$ The latest Rasmussen poll has 28 percent of respondents saying that the Supreme Court is doing a "good" or "excellent" job, while 26 percent rated the Court's performance as "poor." Rasmussen Reports, Supreme Court Update, March 26, 2014, available at http://www.rasmussenreports.com/public_content/politics/mood of america/supr eme court update. By comparison, Congress's numbers were 7 percent "good" or "excellent" and 64 percent "poor." Id.

${ }^{78}$ KRAMER, supra note 9, at 228; see also id. at 232, $333 \mathrm{nn}$. 5-8 (citing the same surveys cited in note 74 , supra).

${ }^{79} I d$. at 232. 
to views about the Constitution held by "the People themselves." That is the thesis of Barry Friedman's recent history of the relationship between the Supreme Court and public opinion. ${ }^{80}$ Professor Friedman concludes that "[o]ver time, through a dialogue with the justices, the Constitution comes to reflect the considered judgment of the American people regarding their most fundamental values. It frequently is the case that when judges rely on the Constitution to invalidate the actions of the other branches of government, they are enforcing the will of the American people." 81 On this view, constitutionalism inside and outside the courts are not wholly different categories; rather, each influences the other over time.

As Friedman points out, moreover, this dialogue is a way of managing "the intractable tension between majority rule and constitutionalism that is innate to the American system of government." " 22 It may well be that the American people do not simply want their own way at all times; rather, they also want to be bound by law to respect constitutional processes and minority rights. ${ }^{83}$ Notably, today's constitutionally-oriented social movements of both left and right-such as the gay rights movement, proponents of gun rights, and the Tea Party - have not attacked and often invited judicial review as part (but only part) of their strategies for social change. At the end of the day, the various academic revolts against judicial review have done a valuable service by supplementing our understanding of the processes shaping constitutional meaning, but they have hardly displaced the courts' central role.

\section{Constitutionalism in Politics}

We are unlikely to do away with judicial review, or to adopt drastic measures - e.g., impeachments, jurisdiction-stripping — punishing wayward courts when they disagree with public opinion on particular questions. Judicial review is simply too much a part of the American fabric, and the academic outrage against our moderately conservative Supreme Court that prompts much popular constitutionalist writing does not seem to be shared by the general public. But the

${ }^{80}$ Barry Friedman, The Will of the PeOPle: How Public Opinion HaS

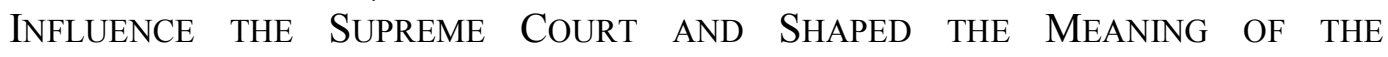
CONSTITUTION (2009).

${ }^{81} \mathrm{Id}$. at 367-68.

${ }^{82} I d$. at 367.

${ }^{83}$ See, e.g., Robert C. Post \& Reva B. Siegel, Democratic Constitutionalism, in The Constitution IN 2020, at 25, 27-28 (Jack M. Balkin \& Reva Siegel, eds. 2009); see also 1 LAURENCE H. TRIBE, AMERICAN CONSTITUTIONAL LAW $§ 1-8$, at 18-24 (3rd ed. 2000) (discussing the constitutionalist desire to tie oneself to the mast). 
intellectual ferment of popular constitutionalism has shed considerable light on the many ways in which constitutionalism outside the courts already plays a critical role in our polity. I discuss four here: the protection of particular constitutional values through political processes and institutional checks; the role of social movements in shaping constitutional meaning; resolution of particular constitutional controversies in the political branches through processes of "constitutional construction"; and the role of "administrative constitutionalism."

These phenomena have a common theme. They each address constitutional questions - that is, issues like the balance of power between state and national governments or discrimination against women and racial minorities. But these forms of constitutionalism tend to answer those questions through extra-constitutional means, by enacting and interpreting statutes or establishing conventions of governmental practice. They thus highlight the extent to which constitutionalism flourishes in our polity not simply outside the courts, but outside the Constitution itself.

\section{A. Political Safeguards}

American debates about the meaning of the Constitution's federal structure reproduce in microcosm the larger debates about the legitimacy of judicial review itself. ${ }^{84}$ Writing in 1954, Herbert Wechsler challenged the need for judicial review of federalism issues, suggesting that "the Court is on weakest ground when it opposes its interpretation of the Constitution to that of Congress in the interest of the states, whose representatives control the legislative process and, by hypothesis, have broadly acquiesced in sanctioning the challenged Act of Congress." ${ }^{" 85}$ A quarter-century later, Jesse Choper urged the Court to abandon judicial review of both federalism and separation of powers issues entirely in order to preserve its political capital for individual rights cases. ${ }^{86}$ Both scholars relied on the expectation that structural values can be adequately preserved through a form of constitutionalism outside the courts - that is, the political and institutional checks and balances that operate through the ordinary political process.

\footnotetext{
${ }^{84}$ Indeed, the Rehnquist Court's federalism decisions seem to be what set Dean Kramer off. See, e.g., Kramer, Foreword, supra note Error! Bookmark not defined., at 138-53.

${ }^{85}$ Herbert Wechsler, The Political Safeguards of Federalism: The Role of the States in the Composition and Selection of the National Government, 54 Colum. L. REV. 543, 559 (1954).

${ }^{86}$ Jesse H. Choper, Judicial Review AND the National Political Process: A FunCtionAl RECONSIDERATION OF THE ROLE OF THE SUPREME COURT 2-3 (1980).
} 
Legal scholars have slaughtered forests debating whether political and institutional safeguards are sufficient to protect constitutional federalism principles (curiously, Dean Choper's suggestion has never been taken all that seriously with respect to separation of powers). ${ }^{87}$ The Court has never accepted the view that they are. ${ }^{88}$ But it remains clear that these extra-judicial safeguards are the primary mechanisms for protecting structural values. ${ }^{89}$ As Brad Clark has explained, "federal lawmaking procedures ... preserve federalism both by making federal law more difficult to adopt, and by assigning lawmaking power solely to actors subject to the political safeguards of federalism" - that is, to Congress, which in turn is made up of representatives beholden to the States. ${ }^{90}$ Moreover, a wide variety of wholly extra-constitutional structures, from the

${ }^{87}$ See, e.g., Larry D. Kramer, Putting the Politics Back into the Political Safeguards of Federalism, 100 Colum. L. REV. 215, 219 (2000) (criticizing Wechsler's version of the political safeguards argument, and substituting an argument based on political parties); Saikrishna B. Prakash \& John C. Yoo, The Puzzling Persistence of Process-Based Federalism Theories, 79 TeX. L. ReV. 1459 (2001) (criticizing political safeguards arguments generally); Lynn A. Baker $\&$ Ernest A. Young, Federalism and the Double Standard of Judicial Review, 51 DUKE L. J. 75 (2001) (arguing that there is no reason to suspend judicial review for federalism but not other constitutional issues). One suspects that the lack of an equivalent debate about separation of powers may be attributed to shared concerns on both Left and Right about institutional overreaching among the branches of the federal government. The contrasting enthusiasm for the "political safeguards of federalism," on the other hand, exists because for many years most liberal legal scholars viewed federalism as a discredited principle unworthy of respect. See, e.g., Seth Kreimer, Federalism and Freedom, 574 AnNals Am. ACAD. POL. \& Soc. SCI. 66, 67 (2001)

${ }^{88}$ The closest the Court has come is Justice Blackmun's majority opinion in Garcia v. San Antonio Metropolitan Transit Authority, 469 U.S. 528 (1985), which rejected an extra-textual limit on federal regulation of state governmental institutions themselves. But in other cases, the Rehnquist and Roberts Courts have heeded Professor Wechsler's own concession that the Court may not "decline to measure national enactments by the Constitution when it is called upon to face the question in the course of ordinary litigation." Wechsler, supra note 85, at 559. See, e.g., Nat'l Fed'n of Ind. Bus. v. Sebelius, 132 S. Ct. 2566 (2012); United States v. Lopez, 514 U.S. 549 (1995).

${ }^{89}$ See Ernest A. Young, Two Cheers for Process Federalism, 46 VILL. L. Rev. 1349, 1353-55 (2001).

${ }^{90}$ Bradford R. Clark, Separation of Powers as a Safeguard of Federalism, 79 TEX. L. REV. 1321, 1324 (2001). 
structure of the political parties to state lobbying organizations like the National Governors Association to the role of state bureaucrats implementing federal regulatory schemes, have grown up to permit states to influence the operation of federal policy. ${ }^{91}$

In a sense, political safeguards for structural principles are not "constitutionalism" at all. Members of Congress who oppose federal legislation typically do so because they think it is bad policy, or because it threatens the interests of their constituents - not because they think it contravenes constitutional principles of federalism. And state bureaucrats who push implementation of federal programs typically do so for policy reasons, not constitutional ones. Nonetheless, the structure of the lawmaking process protects state autonomy by making it relatively easy for opponents of federal legislation to block federal legislation; likewise, the structure of federal regulatory programs provides numerous opportunities for influence, foot-dragging, and outright subversion by state officials charged with implementing federal laws. ${ }^{92}$ These dynamics, in turn, protect the constitutional value of state autonomy. This is constitutionalism not simply outside the courts but on auto-pilot, dating back at least to Madison's reliance on "opposite and rival interests . . . in all the subordinate distributions of power" to hold the constitutional structure in place. ${ }^{93}$

\section{B. Social Movements}

Much constitutional scholarship in recent years has focused on the role of social movements-such as the African American civil rights movement, the women's rights movement, or the movement for gun rights - in shaping constitutional meaning. As Reva Siegel has explained, "[s]ocial movements change the ways Americans understand the Constitution. Social movement conflict, enabled and constrained by constitutional culture, can create new forms of constitutional understanding - a dynamic that guides officials interpreting the open-textured language of the Constitution's rights guarantees." 94 Social movements may reinforce and extend the constitutional vision articulated by the

${ }^{91}$ See generally John D. Nugent, SAFeguarding Federalism: How States Protect THeir INTERESTS IN NATIONAL POLICYMAKING (2009).

${ }^{92}$ See generally Jessica Bulman-Pozen \& Heather K. Gerken, Uncooperative Federalism, 118 YALE L. J. 1256 (2009).

${ }^{93}$ The Federalist No. 51, supra note 39, at 349 (James Madison).

94 Reva B. Siegel, Constitutional Culture, Social Movement Conflict and Constitutional Change: The Case of the de facto ERA, 94 CAL. L. REV. 1323, 1323 (2006); see also Robert Post \& Reva Siegel, Roe Rage: Democratic Constitutionalism and Backlash, 42 HARV. CIVIL-RIgHTS CIVIL-LIB. L. REV. 373 (2007). 
Court, as the civil rights movement did in the years after Brown, or they may run counter to established constitutional interpretations, as the gun rights movement did in the years prior to District of Columbia v. Heller. ${ }^{95}$ In either case, they represent a classic form of constitutionalism outside the courts.

While the importance of social movements is obvious, the precise ways in which they shape constitutional meaning - in particular, the ways in which a movement's vision gets translated into constitutional law-is less clear. Jack Balkin has identified two distinct institutional paths by which social movements may influence the development of constitutional law. The first runs through political parties and judicial appointments: "social movements . . influence the two major political parties, which, in turn, control the system of judicial appointments." ${ }^{" 66}$ Hence, social activism "leads to the appointment of judges who sincerely believe that the best interpretation of the Constitution is one that happens to be sympathetic with social movement claims." Professor Balkin and Sanford Levinson have called this mechanism "partisan entrenchment," reflecting the likelihood that judges appointed by political partisans may outlast the political force of the social movement that brought them to the bench. ${ }^{97}$

The second path involves the influence of social movements on "the values of national elites." A8 According to Professor Balkin, "[s]ocial movement politics play a crucial role in getting both popular and elite opinion to view the world differently and to acknowledge changes as salient and important." 99 This path differs from the first in that "[a]ppeals to national elite values try to change constitutional doctrine by changing the minds of sitting judges," which tend to reflect elite opinion, "while the strategy of partisan entrenchment tries to change the judges." 100 Other institutional mechanisms may also be important. As I discuss further in Section D, social movements may also succeed in enacting legislation, such as the 1964 Civil Rights Act, which in turn shape the development of constitutional law.

${ }^{95} 554$ U.S. 570 (2008); see generally Reva B. Siegel, Dead or Alive: Originalism as Popular Constitutionalism in Heller, 122 HARV. L. REV. 191 (2008).

${ }^{96}$ Jack M. Balkin, How Social Movements Change (or Fail to Change) the Constitution: The Case of the New Departure, 39 Suffolk U. L. Rev. 27, 30 (2005).

97 Jack M. Balkin \& Sanford Levinson, Understanding the Constitutional Revolution, 87 VA. L. REV. 1045, 1067 (2001).

${ }^{98}$ Balkin, supra note 96 , at 32 .

${ }^{99}$ Id. a 34.

${ }^{100} I d$. at $32-33$. 
The contrast between this conception of popular constitutionalism and Dean Kramer's is instructive. Kramer advocated extraordinary measures to disobey, overturn, or intimidate the courts; the popular constitutionalism of Professors Siegel, Balkin, and others, by contrast, operates by persuading the institutions of government (including courts) to act through established channels (including judicial review). As such, the latter view is likely to be far more congenial to an American public that retains considerable respect for both the courts and the role of judicial review.

Broad-based forms of popular constitutionalism may be particularly influential with respect to principles of constitutional law that are "underenforced" in current doctrine. ${ }^{101}$ Larry Sager has demonstrated that much constitutional doctrine stops short of implementing the full normative content of particular constitutional provisions, instead deferring to political actors on institutional grounds. ${ }^{102}$ Examples in current law would include the constitutional limits on delegation of legislative authority to administrative agencies, discrimination against non-suspect classes, and legislation impairing the obligation of contracts. In each of these areas, courts have not felt confident in substituting their own judgment for those of the governmental actors subject to judicial review. ${ }^{103}$ The extent to which any given constitutional principle is underenforced, however, is historically contingent; many principles have been both rigorously enforced and underenforced at different periods of our history. ${ }^{104}$ When the underlying constitutional culture that had supported judicial deference changes, the Court's doctrine may change too. ${ }^{105}$

${ }^{101}$ See Ernest A. Young, Popular Constitutionalism and the Underenforcement Problem: The Case of the National Healthcare Law, 75 L. \& CONTEMP. Probs. 157, 193-98 (2012).

${ }^{102}$ See Lawrence Gene Sager, Fair Measure: The Legal Status of Underenforced Constitutional Norms, 91 HARV. L. REV. 1212 (1978).

${ }^{103}$ See, e.g., United States v. Lopez, 514 U.S. 549, 604 (1995) (Souter, J., dissenting) (explaining that rational basis review under the Commerce Clause "reflects our respect for the institutional competence of the Congress on a subject expressly assigned to it by the Constitution and our appreciation of the legitimacy that comes from Congress's political accountability in dealing with matters open to a wide range of political choices").

${ }^{104}$ See Young, Popular Constitutionalism, supra note 101, at 182-85.

${ }^{105}$ See id. at 181-82. 
Constitutional doctrine frequently trades on notions of what is "normal." "106 In the middle of the last century, Americans tended to look to the national government for solutions to social problems - an expectation reflected in high trust levels for national institutions compared to state and local ones. ${ }^{107}$ But conceptions of normalcy can change, often in response to the efforts of social movements. The Court's more vigorous enforcement of federalism limits on national power has occurred contemporaneously with a significant shift in public trust away from national institutions toward state and local ones and a more general skepticism of national regulation reflected in the Tea Party movement. ${ }^{108}$ Likewise, the gay rights movement has changed conceptions of what counts as a "marriage" or a "family" in ways that are beginning to be reflected in constitutional doctrine. ${ }^{109}$ Participants in these movements need not think of themselves as interpreting the Constitution in order to shape the way that constitutional principles are implemented.

\section{Constitutional Construction}

Non-judicial actors do not simply interpret the Constitution; sometimes they have to fill in the gaps. Keith Whittington's concept of constitutional "construction" addresses this function, which rests on the fact that "[t]he various branches of government not only share overlapping powers ... they also possess distinctive perspectives, resources, and capacities that help to shape political outcomes." 110 To be sure, some of the work that political branch officials do is interpretive in the same sense as judicial interpretation. But often political actors do something quite different. As Professor Whittington explains, "constructions do not pursue a preexisting if deeply hidden meaning in the founding document; rather they elucidate the text in the interstices of discoverable, interpretive

${ }^{106}$ See, e.g., Jack M. Balkin, From Off the Wall to On the Wall: How the Mandate Challenge Went Mainstream, THE ATLANTIC, June 4, 2012, available at http://www.theatlantic.com/national/archive/2012/06/from-off-the-wall-to-on-thewall-how-the-mandate-challenge-went-mainstream/258040/.

${ }^{107}$ See Megan Mullin, Federalism, in Persily, CITRIN, \& EgAn, supra note 74, at 209, 216-19.

${ }^{108}$ See Young, Popular Constitutionalism, supra note 101, at 193-98; see also FRIEDMAN, supra note 80, at 194 (concluding that the Rehnquist Court's "federalist revival" was broadly consistent with American public opinion); Mullin, supra note 107, at 214 (analyzing the shift in public trust in favor of the states).

${ }^{109}$ See, e.g., United States v. Windsor, 133 S. Ct. 2675 (2013).

${ }^{110}$ Keith E. Whittington, Constitutional Construction: Divided Powers and Constitutional MeAning 19 (1999). 
meaning, where the text is so broad or so underdetermined as to be incapable of faithful but exhaustive reduction to legal rules." 111

Just as social movements may have the most influence in elevating constitutional principles that were previously underenforced, so too constitutional construction has the most room to operate in areas where the constitutional text is indeterminate. Over the course of our history, the political branches have had to confront numerous questions that are constitutional in character, but on which the Constitution and its associated interpretive materials provide no answer. Examples include the proper standard for impeaching federal judges or the scope of the President's power to remove executive officials once appointed and confirmed by the Senate. ${ }^{112}$ While interpretation involves a search for preexisting meaning by an ideally objective interpreter, construction is a process by which political actors with partisan stakes create meaning within the space afforded by constitutional indeterminacy. Judges tend to play a minimal or nonexistent role in this process.

The notion of constitutional construction by political actors raises as many questions as it answers. One concerns the precedential force of political practice when the legality of the construction is challenged in court. ${ }^{113}$ One response would be to say that because legitimate construction occurs in the interstices that the constitutional text leaves open, one prerequisite of a construction's validity is that the space is, in fact, open. If the underlying constitutional principles are not, in fact, indeterminate, then their interpretive meaning must control. One might draw an analogy to the Chevron doctrine in administrative law, which requires courts to defer to constructions of federal statutes by administrative agencies - but only if the underlying statutory provision is ambiguous. ${ }^{114}$ On the other hand, a settled construction by political actors is likely to influence the way that a court

${ }^{111} \mathrm{Id}$. at 5. Judges, too, sometimes engage in construction as opposed to interpretation. See Lawrence B. Solum, The Interpretation-Construction Distinction, 27 Const. COMmentary 95, 103-04 (2010); Keith E. Whittington, Constructing a New American Constitution, 27 CONST. COMMENTARY 119, 128 (2010) (agreeing that "[i]t would . . . be overstated to think of the interpretationconstruction distinction strictly in institutional terms"). But one of the principal contributions of "construction" as a conceptual alternative to "interpretations" has been to supply a more satisfying account of the ways in which extra-judicial actors participate in the creation of constitutional meaning.

${ }^{112}$ See WhitTington, supra note 110, at 20-71, 113-157.

${ }^{113}$ See generally Curtis A. Bradley \& Trevor W. Morrison, Presidential Power, Historical Practice, and Legal Constraint, 113 CoLUM. L. REV. 1097 (2013).

${ }^{114}$ See Chevron, U.S.A., Inc. v. Natural Resources Defense Council, Inc., 467 U.S. 837 (1984). 
reads the underlying constitutional principles. And that construction may, in some circumstances, have staying power even in the event of judicial invalidation.

The Court's decision on the legislative veto provides an example. A perennial problem in separation of powers law concerns the extent to which Congress may delegate lawmaking power to the executive and the means by which it may control the exercise of that power. The Constitution says little directly about this question, and what it does say-that all of the national legislative power is vested in Congress ${ }^{115}$ - seems impracticable under modern circumstances. Beginning in the 1930s, Congress qualified some of its delegations to the Executive with legislative veto provisions, which allowed it to override particular executive actions pursuant to delegated authority without going through the difficult procedure specified in Article I for enacting a new statute. ${ }^{116}$ By the 1980 s, nearly 200 legislative veto provisions were scattered throughout the U.S. Code; it seems fair to say that although the President continued to raise constitutional objections from time to time, Congress had succeeded in securing practical acquiescence to its construction. This did not stop the Court from holding the legislative veto unconstitutional, however, in INS v. Chadha ${ }^{117}$ on the ground that it permitted Congress to act with legal force in a way that departed from the "single, finely wrought and exhaustively considered, procedure" specified in Article I. Nonetheless, Congress has continued to enact legislative veto provisions in the years after Chadha, and the executive branch largely complies with them as a matter of practical necessity. ${ }^{118}$ Although the Chadha decision means that these vetoes are no longer legally enforceable by judicial order, the political branches' construction retains life outside the courts.

\section{Administrative Constitutionalism}

A final approach to constitutionalism outside the courts rejects the "romantic understanding of the judge-enforced Constitution" in favor of "a more realistic view" centered on the enactment and implementation of federal statutes. ${ }^{119}$ William Eskridge and John Ferejohn begin their account of democratic constitutionalism with the observation that "the written Constitution left many things essentially unresolved, including the extent of the franchise for federal and state elections, the precise authority of the president, the extent and

\footnotetext{
${ }^{115}$ U.S. CONST. art. I, $\S 1$.

116 See Louis Fisher, The Politics of Shared Power: Congress And the EXECUTIVE 91-93 (4 ${ }^{\text {th }}$ ed. 1998).

117462 U.S. 919, 951 (1983)

118 See FISHER, supra note 116, at 99-104.

${ }^{119}$ ESKRIDGE \& FEREJOHN, supra note 10, at 4.
} 
reach of the federal judiciary, and the role of judges in enforcing rights." ${ }^{120}$ Moreover, "the Constitution's high hurdle for formal amendment limited the extent to which the continuing struggle over the content of our democratic constitutionalism . . . could be resolved as a matter of Large ' $\mathrm{C}$ ' Constitutional law. " 121 Conventional constitutional theory holds that these gaps have been filled in largely through the process of judicial review, with common law elaboration providing the necessary play in the joints that allows an old and hard-to-amend constitution to remain relevant to contemporary society. Professors Eskridge and Ferejohn, by contrast, contend that the primary instruments of constitutional change have been statutes, executive orders and agency rules, and treaties and other agreements.

Like many of the other accounts of popular constitutionalism already considered, the "administrative constitutionalism' of Professors Eskridge and Ferejohn is avowedly ideological in motivation. The conventional judge-centered account, they argue, has a libertarian bias-judges are good at elaborating individual rights and structural principles that check the power of government, but bad at "address[ing] the duties of government to create and guarantee affirmative and positive legal regimes that provide security and structure for American public finance, families, employment and commercial activities, old-age and disability insurance, and national defense." 122 These duties-reminiscient of Professor Tushnet's "thin constitution" consisting of the Declaration of Independence and the Preamble ${ }^{123}$ - are best vindicated through our "Republic of Statutes." 124

Administrative constitutionalism is a form of popular constitutionalism in the sense that "the ultimate form of political agency is found in We the People, acting through regular elections and the associated devices of political parties but also by means of political associations and interest groups and through popular social movements." 125 Nonetheless, "the primary governmental actors are legislators, executive officials, and administrators" who promulgate, interpret, and implement statutes and other subconstitutional legal directives. ${ }^{126}$ Hence the term "administrative constitutionalism."

${ }^{120} I d$. at 3.

${ }^{121} I d$.

${ }^{122} I d$. at 5.

${ }^{123}$ See supra notes ___ and accompanying text.

${ }^{124}$ ESKRIDGE \& FEREJOHN, supra note 10, at 5-6.

${ }^{125} I d$. at 1 .

${ }^{126} \mathrm{Id}$. 
The great virtue of this approach is that it allows conceptual space for the two distinct faces of constitutionalism, even if Professors Eskridge and Ferejohn do not give those faces equal prominence. One face, emphasized by popular constitutionalists, views the Constitution as "the vehicle by which a democratic polity develops its own fundamental values." ${ }^{127}$ This strand tends to emphasize government empowerment, and it looks naturally-as Eskridge, Ferejohn, and Tushnet all do - to the statements of governmental purpose in the Preamble. The other face of constitutionalism emphasizes constraint; the Constitution, on this view "incorporates a series of rules that impose second-order constraints on the first-order policy preferences of the people and their elected representatives and executive officials." ${ }^{\prime 28}$ Stressing constraint tends to shift our focus not only to negative liberties against government but also to the structural hurdles that the Constitution raises against government action. ${ }^{129}$

Like most analytical typologies, this one fails to capture the full complexity of the subject. The equality principle in the Fourteenth Amendment is both a constraint on discriminatory government activity and a value to be realized through positive government action. And such Preamble-driven action may be necessary to render negative constraints on government effective; public education of the citizenry, for instance, plays a critical role in developing not only a vibrant marketplace of ideas under the First Amendment but also an informed electorate capable of checking politicians at the ballot box. Nonetheless, the difference between the two faces of constitutionalism helps to explain why proponents and critics of popular constitutionalism so often talk past one another. Popular constitutionalism makes sense for the first face; it is hard to argue that unelected judges should have exclusive or even primary authority to define national values and pursue the affirmative ends of government. But external constraint on the pursuit of those ends is an important (if not the only) aspect of the second face. Our tradition has generally relied on judges to provide that external constraint on political action. ${ }^{130}$

Administrative constitutionalism focuses on the government-empowering first face of constitutionalism, but it generally does not take strong anti-judicial review positions that undermine the Constitution's external constraint function. This leaves room for disaggregating those functions as a matter of constitutional theory. In other work, I have distinguished three primary functions of constitutions: constituting the government (creating governmental institutions

${ }^{127}$ Frederick Schauer, Judicial Supremacy and the Modest Constitution, 92 CAL. L. REV. 1045, 1045 (2004).

${ }^{128}$ Schauer, supra note 127 , at 1046.

${ }^{129}$ See, e.g., Clark, supra note 90.

${ }^{130}$ See Schauer, supra note 127, at 1056-59. 
and delimiting their jurisdiction, procedures, and powers); creating rights; and entrenching certain principles against constitutional change. ${ }^{131}$ A key insight of administrative constitutionalism is that all of these functions are performed not only by the canonical text of 1789 and its subsequent formal amendments, but also by statutes, regulations, and settled government practices. ${ }^{132}$ As Karl Llewellyn put it back in 1934, "most of the going framework of our Leviathan is hardly adumbrated in the Document. As a criterion of what our working Constitution is, the language fails in both directions. It affords neither a positive nor a negative test." 133

Popular constitutionalism encourages political actors to flesh out the constitutive framework of our government and to expand the catalog of rights that people have. It may even entrench these reforms, as a practical matter, by establishing programs with enduring bases of popular support. ${ }^{134}$ Political actors can generally undertake these actions without running afoul of the judgedominated constraining face of constitutionalism because the Constitution is either silent or permissive on most of the relevant questions. As Fred Schauer puts it, "[t]he Constitution . . . says remarkably little about what the government should do, and that is as it should be."135 The limits are not nonexistent, and sometimes efforts to extend the reach of governmental programs, alter governmental frameworks, or create new entitlement will run into serious constitutional constraints. ${ }^{136}$ But in general the Constitution allows considerable room for development and elaboration without implicating the constraining function of the courts.

This is an important advantage, because theories of popular constitutionalism that must disparage the constraining function of judicial review risk losing track of something important. The notion that certain principles remain off limits from infraction, no matter how good the intentions of

${ }^{131}$ See Ernest A. Young, The Constitution Outside the Constitution, 117 YALE L. J. 408, 415-16 (2007).

${ }^{132}$ See ESKRIDGE \& FEREJOHN, supra note 10, at _ ; see also Young, supra note 131 , at $417-28$.

${ }^{133}$ K. N. Llewellyn, The Constitution as an Institution, 34 CoLuM. L. REv. 1, 15 (1934).

${ }^{134}$ Consider, for example, whether we are more likely to see a formal constitutional amendment prohibiting flag burning or a statute repealing the Social Security program.

${ }^{135}$ Schauer, supra note 127, at 1065.

${ }^{136}$ See, e.g., NFIB v. Sebelius, 132 S. Ct. 2566 (2012); Clinton v. City of New York, 524 U.S. 417 (1998). 
government actors or how sound their policy arguments, still stands at the heart of American constitutionalism. A good theory of popular constitutionalism needs an account of constitutional change outside the formal amendment process, a theory by which constitutional principles and values can guide the positive actions of government, and room for the continuing importance of judicial review's constraining function.

It is also worth noting that administrative constitutionalism is not entirely a theory of constitutionalism outside the courts. After all, the statutes, administrative regulations, treaties, and the like that flesh out our constitutional structure and values are themselves generally subject to judicially interpretation and enforcement. For example, as Cass Sunstein has observed, "Broad delegations of power to regulatory agencies, questionable in light of the grant of legislative power to Congress in Article I of the Constitution, have been allowed largely on the assumption that courts would be available to ensure agency fidelity to whatever statutory directives have been issued." 137 Administrative constitutionalism thus not only leaves room for traditional judicial review in constitutional cases, but it also does not get off the ground without expanding the reach of judicial review to cover the Constitution outside the Constitution.

\section{Conclusion}

Theories of constitutionalism outside the courts have both a positive and a negative project. On the positive side, they remind us that the Constitution belongs to all of us - not just judges, but also legislators, bureaucrats, executive officials, and private citizens. All of these actors have both the opportunity and the responsibility to interpret and implement constitutional principles, and all of these actors have a role in the development of those principles over time. This has always been true, and the Founders knew it well. But constitutional scholars, lawyers and judges are always at risk of forgetting, and the reminder that scholars of popular constitutionalism have provided is a valuable contribution indeed.

The negative project is to attack judicial review. Some of this critique reflects longstanding concerns about the anti-democratic nature of the institution and the indeterminacy of constitutional principle, which leaves room for the entry of the judges' own political preferences. But the popular constitutionalism literature also reflects something of a shift in the orientation of liberal constitutional theory. Perhaps because the judiciary has become more conservative than in the heyday of the Warren Court, and perhaps because liberals have recently enjoyed somewhat more sway in the political branches than they once did, many progressives have come to prefer the constitution outside the courts. Although political liberals once championed the Court's role in enforcing

137 Cass R. Sunstein, After the Rights Revolution: Reconceiving the REGULATORY STATE 143 (1990). 
the Free Speech Clause of the First Amendment, for example, it has now become fashionable for them to reject that role. ${ }^{138}$ We have, in some ways, returned to the political alignments of the Progressive Era and the New Deal, when conservatives took refuge in the courts and liberals championed action by the political branches and the regulatory bureaucracy. It is sufficient commentary on this development to observe that what can change once can change again.

As Governor of Arkansas, Orval Faubus was correct in undertaking to interpret the Constitution for himself and in acting on that interpretation in the performance of his official functions. It is important to get the Constitution right, however, and history rightly condemns Faubus because he interpreted the Constitution poorly, and in a way that harmed citizens who deserved better. Faubus was wrong, moreover, to interfere with the courts' ultimate settlement function in litigated constitutional controversies. If the Constitution is to continue to act as an external constraint on political action, then constitutionalism outside the courts can never be wholly autonomous of constitutionalism inside.

${ }^{138}$ Compare, e.g., ANTHONy Lewis, MAKE No LAW: The SUlLIVAN CASE AND THE First Amendment (1992), with E. J. Dionne, Supreme Oligarchy, WASH. Post, April 6, 2014, available at http://www.washingtonpost.com/opinions/ej-dionne-jrsupreme-oligarchy/2014/04/06/823f15ea-bc2e-11e3-9a05-

c739f29ccb08_story.html. 